NBER WORKING PAPER SERIES

RETHINKING SOCIAL INSURANCE

Martin Feldstein

Working Paper 11250

http://www.nber.org/papers/w11250

\author{
NATIONAL BUREAU OF ECONOMIC RESEARCH \\ 1050 Massachusetts Avenue \\ Cambridge, MA 02138 \\ March 2005
}

The views expressed herein are those of the author(s) and do not necessarily reflect the views of the National Bureau of Economic Research.

C2005 by Martin Feldstein. All rights reserved. Short sections of text, not to exceed two paragraphs, may be quoted without explicit permission provided that full credit, including $\odot$ notice, is given to the source. 
Rethinking Social Insurance

Martin Feldstein

NBER Working Paper No. 11250

March 2005

JEL No. H5

\begin{abstract}
$\underline{\text { ABSTRACT }}$
This paper begins by discussing the nature of and rationale for social insurance programs. I then consider three political principles and four economic principles that could guide the design and reform of social insurance programs. These ideas are then applied to unemployment insurance, Social Security pensions, health insurance and Medicare. A common theme is the advantage of incorporating investment based personal accounts in each of these programs.

Martin Feldstein

National Bureau of Economic Research

1050 Massachusetts Avenue

Cambridge, MA 02138-5398

mfeldstein@nber.org
\end{abstract}




\title{
Rethinking Social Insurance
}

\author{
Martin Feldstein*
}

I will speak today about Social Insurance, a subject I have been studying for nearly 40 years. The intellectual and policy revolution in social insurance that is occurring around the world is among the most significant and positive developments of current economics. I am pleased to share my thoughts on this subject with my fellow economists and honored by this opportunity to deliver the Presidential address of our association. ${ }^{1}$

Social insurance programs have become the most important, the most expensive, and often the most controversial aspect of government domestic policy, not only in the United States but also in many other countries, including developing as well as industrial nations. In the United States, these programs include Social Security retirement, disability and survivor insurance, unemployment insurance, and the Medicare health insurance for those age 65 and older. Together they accounted in 2003 for 37 percent of federal government spending and more than 7 percent of GDP. These ratios have increased rapidly in the past and are projected to increase even faster in the future because of the more rapid aging of the population.

Today I will discuss how the major forms of social insurance could be improved by shifting to a system that combines government insurance with individual investment-based accounts: Unemployment Insurance Savings Accounts backed up by a government line of credit, Personal Retirement Accounts that supplement ordinary pay-as-you-go Social Security benefits, and Personal Retirement Health Accounts that finance a range of Medicare choices. I think that such reforms would raise economic well-being and are also appealing on broader philosophical grounds.

AER.Jan3 
Several nations are now doing this for their retirement programs, including such diverse countries as Australia and Mexico, England and China, Chile and Sweden (See Feldstein, 1998, Feldstein and Siebert, 2002). The focus by governments around the world on social insurance pension reform is driven in part by the realization that the aging of their populations implies that the tax rates required to fund social insurance pension benefits will rise rapidly if the programs are not changed.

The impetus for broader social insurance reform comes from the recognition that existing programs have substantial undesirable effects on incentives and therefore on economic performance. Unemployment insurance programs raise unemployment. Retirement pensions induce earlier retirement and depress saving. And health insurance programs increase medical costs. Governments are driven by a desire to reduce the economic waste and poor macroeconomic performance that these disincentives create and to avoid the resulting tax consequences as well as the increased tax cost of the aging population.

Economic research has helped policy officials to recognize these undesirable effects and to redesign social insurance programs. The pace of reform and the nature of the program changes differ from country to country, reflecting initial conditions and local political realities. Reforms are inevitably only partial and part of an ongoing process. But the reforms generally make the programs more economically efficient, providing more protection relative to the financial costs and the economic distortions. I will examine some of the favorable changes that have already occurred in the U.S. unemployment, retirement, and health care programs.

Before looking at these specific types of social insurance, I want to discuss three general questions. Just what is social insurance? Why do or should we have such programs? And what AER.Jan3 
are the principles by which such programs should be evaluated and redesigned?

\section{Social Insurance and Welfare Programs}

The word "insurance" is used to describe these transfer programs because they deal with risks: the risk of job loss, of health care expenses, and of inadequate assets during retirement. But social insurance is very different from private insurance. The key distinction is that participation in social insurance programs is mandatory or is induced by substantial fiscal subsidies.

Social insurance programs are also very different from welfare programs. Welfare benefits are means tested, i.e., they are paid only to those with incomes (and assets) below some level. In the United States, these means tested programs include Medicaid, food stamps, subsidized housing, school lunches, and others. ${ }^{2}$ In contrast, social insurance programs are "event conditioned." Benefits are paid when some event occurs in an individual's life regardless of the individual's income or assets. Unemployment benefits are paid to those who lose their jobs, Medicare benefits to those who are ill and over 65, Social Security benefits are available to those over age 62, disability benefits to those unable to work, and survivor benefits to the widows and children of deceased workers.

Unlike welfare programs, social insurance programs are not designed to be vehicles for income redistribution. Although some fraction of social insurance outlays are paid to those with low incomes, most of the benefits go to middle and higher income households. This is particularly true in the United States where cash benefits to retirees and the unemployed are positively related to previous earnings and where health care is largely provided by private hospitals and physicians even when financed by social insurance.

Social insurance may appear to be redistributing income to the poor because benefits are paid to those who are temporarily poor because of the event that triggered the payment of benefits. This AER.Jan3 
ignores the permanent or lifetime income of these recipients. It also ignores the effect of the social insurance on the incentive to accumulate funds for these rainy days. Social Security benefits that replace 50 percent or more of after-tax pre-retirement income reduce significantly the incentive to save for old age and therefore depress income in retirement. Unemployment benefits with high replacement rates have a similar effect on saving to finance spells of unemployment.

The lack of redistribution is well illustrated by the Social Security retirement program. A new retiree last year who had annual earnings at or above the Social Security program's maximum taxable amount ( $\$ 87,900$ in 2004) for at least 35 years received a benefit of $\$ 21,900$. In contrast, someone with lifetime earnings in the middle of the earnings distribution received only about twothirds as much in retirement benefits. And someone with low earnings (i.e., 45 percent the average wage) received benefits of less than $\$ 9,000$ a year. This lack of redistribution is compounded by the rules governing benefits to spouses and widows. A retiree who previously had maximum taxable income and who retired with a dependent spouse received more than $\$ 32,000$ a year from Social Security while the widow of a low earner would receive less than $\$ 9,000$.

The Social Security program appears to be redistributive because everyone pays the same tax rate while the ratio of benefits to lifetime earnings is designed to fall as those earnings rise. In practice, however, this apparent redistribution is offset by the longer expected life of higher income individuals, their increased use of spouse benefits, and the later age at which they begin to work and to pay taxes . Research by Jeffrey Liebman (2002), based on a large sample of actual individual earnings histories, showed that less than 10 percent of Social Security benefits represented net redistribution across income groups within the same birth cohort. Coronado, Fullerton and Glass (2000) showed that the combination of taxes and benefits for the Social Security program leaves the AER.Jan3 
lifetime Gini coefficient of the population's income essentially unchanged. In addition, the general equilibrium effects of Social Security tilt the pretax distribution of income toward higher income individuals by reducing capital accumulation which in turn lowers real wages and raises the return to capital.

Unemployment Insurance (UI) also does not redistribute to the poor. In Massachusetts, a state considered to have a very generous UI program, the UI benefits were financed in 2003 by a payroll tax on only the first $\$ 10,800$ of earnings (with a zero marginal tax rate above that level) while basic benefits were 50 percent of previous wages up to more than $\$ 50,000$ of wages per year.

An individual who earns $\$ 50,000$ a year pays the same tax as someone who earns $\$ 11,000$ a year but would receive benefits that are nearly five times as high. ${ }^{3}$ Taken by itself this would mean a substantial redistribution from low wage earners to higher wage earners. Moreover, since benefits are paid only to individuals who have earned some minimum amount during the past year, those with long spells of unemployment may not be eligible for any benefits at all.

Although the same Medicare rules apply to everyone over age 65, higher income seniors often get substantially more benefits than those with lower incomes. McClellan and Skinner (1997) concluded that Medicare produced net transfers from the poor to the wealthy as a result of the higher annual expenditures and longer survival times of wealthier Medicare beneficiaries. In the same spirit, Skinner and Zhou (2004) found greater use of mammography screening, diabetic eye exams, and other indicators of good care among high income Medicare groups than among those with lower incomes.

The very high level of spending on the middle class social insurance programs hurts the low income population in another way: they put a drain on the government budget in a way that reduces AER.Jan3 
the funds available for helping the poor. Social insurance programs cost $\$ 800$ billion in 2003 , while federal spending on all means tested programs except Medicaid was less than $\$ 150$ billion. ${ }^{4}$ Over the past four decades, the spending on means tested programs (except Medicaid) has remained relatively constant (rising from 1.0 percent of GDP to 1.3 percent of GDP) while the social insurance programs that are not means tested rose from 2.7 percent of GDP to 7.4 percent of GDP.

The negative effect of social insurance spending on means tested programs is not only an observed fact but is also what optimal tax theory implies. The deadweight burden of an extra dollar of taxes increases with the share of income taken in taxes. The high level of taxes that is needed to finance middle class social insurance programs therefore increases the deadweight burden of any incremental taxes that would be used to finance means tested poverty programs. The large social insurance programs thus reduce the optimal size of means tested poverty programs.

\section{Why Social Insurance?}

Some writers see social insurance in broad philosophical terms, reflecting their specific views of the appropriate role of government in society. One such view, more common in Europe than in the United States, is that social insurance should be judged by its contribution to social solidarity, i.e., to the sense that all of the individuals in the nation are in effect viewed as a single family and treated equally. This leads to the principle of uniform health care for all, although this is more often an asserted political goal than a practical reality. Similarly, they may reject any role for company-based private pensions in order that all workers participate only in a common pay-asyou-go state plan.

Th opposite philosophical view that the provision of health care or retirement income is not a legitimate role for government because it forces individuals to participate in a common program AER.Jan3 
rather than taking personal responsibility and making decisions that reflect their own preferences. Milton Friedman's Capitalism and Freedom (1962) is the classic statement of this view that social insurance programs are inappropriate because they infringe individual liberty.

The social solidarity view is often combined with the statement that individuals are incapable of making the complex decisions required to plan for retirement income or to choose health insurance or health care. The opposite view emphasizes that individuals differ in their tastes and are better able than governments to judge what is in their own best interest.

I believe in the diversity of individual preferences and the ability of most individuals to act in their own self interest. But I also believe that there is a role for government that justifies the provision of social insurance benefits. I come to this conclusion on utilitarian grounds rather than from any philosophical commitment to social solidarity.

There are two distinct reasons for providing social insurance. Both reflect the asymmetry of information. The first is that asymmetric information weakens the functioning of private insurance markets. The second is the inability of the government to distinguish between those who are poor in old age or when unemployed because of bad luck or an irrational lack of foresight from those who are intentionally "gaming" the system by not saving in order to receive transfer payments. Both problems show that the case for social insurance cannot be rejected simply by arguing that such programs force people to act against their own best interests.

But these problems of asymmetric information or any other market failures do not necessarily justify government action. While a perfect and benevolent government would be better than a private market burdened by market imperfections, actual governments are neither perfect nor necessarily benevolent. Political actors do not maximize a social welfare function but reflect political AER.Jan3 
pressures and bureaucratic preferences. Moreover, social insurance programs impose costs that must be weighed against the benefits of overcoming market imperfections. Both require empirical evaluation.

Consider first the asymmetry of information in insurance markets. To be specific, consider the case of private annuities. If individuals can buy annuities on actuarially fair terms they may increase their expected utility by annuitizing their assets at retirement. But if individuals differ in their life expectancy and know more about their mortality prospects than the insurance company can learn, those with shorter life expectancy will want to annuitize a smaller portion of their wealth. Insurance companies will recognize the resulting self selection and offer annuities with premiums that reflect the mortality rates of the long-lived individuals who are their most likely customers. This produces a downward spiral in the demand for annuities that is limited only when at some point the risk-reducing value of annuitizing outweighs the less than actuarially fair pricing of individual annuities.

A mandatory social insurance program like traditional Social Security circumvents this asymmetry of information by providing everyone with a retirement annuity rather than a lump sum at retirement age. But whether this is better than an imperfect private annuity market in which some annuitize little and others not at all depends on the implicit rates of return available on the social insurance annuity, on the private annuity, and on non-annuitized saving. It also depends on the degree of diversity in preferred spending patterns in retirement and in attitudes about bequests, since complete annuitization at retirement would not permit the purchase of retirement homes or other major consumer outlays or the making of bequests or inter vivos gifts.

AER.Jan3 
The problem of information asymmetry in private annuities could be reduced if individuals purchased annuities at relatively young ages before they could accumulate much information about their own likely mortality risks in old age. Alternatively, a mandatory annuity could be more attractive if it were based on the higher return available in an investment-based program rather than in a mature pure tax-financed pay-as-you-go program.

Two conclusions follow from this. First, the existence of asymmetric information may justify a social insurance program (a government annuity in this case) but does not necessarily do so. The case for a mandatory annuity program depends on calculations that could be done but that have not yet been done. Second, the appropriateness of a social insurance program and its optimal size can be increased if the cost of the social insurance option is reduced, something that depends on how it is financed.

Consider now the second form of asymmetric information that might provide a rationale for a social insurance program: the government's inability to distinguish those who are poor through bad luck or inadvertence from those who deliberately chose to act in a way that leads to eligibility for free benefits. A primary reason for social insurance programs is that some individuals would not act in their own interest, saving far too little for their retirement, for health care after they are no longer working, or to finance consumption when they are unemployed. Although some economists may reject the likelihood of such irrational behavior as a basis for policy analysis, as individuals we all recognize that such irrationality exists in practice. Recent work on behavioral economics has helped to make the possibility of such irrationality or myopic behavior a part of mainstream economics.

But such departures from rational saving by a fraction of the population need not justify the general provision of social insurance benefits. Why not simply provide means tested benefits instead AER.Jan3 
of the universal provision of social insurance benefits? The primary reason for not doing that is that some rational and farsighted individuals would be induced by a means tested system to act in a way that allows them to qualify for benefits. Doing so would impose tax costs on the rest of the population that could make overall well-being lower than in a universal (i.e., not means tested) program.

Consider a simple example of a means tested retirement program (Feldstein, 1987). Assume that some fraction of the population is myopic and would not save anything for retirement. A means tested program would provide a benefit for all such myopic retirees. How would rational workingage individuals respond to such a system? They would have the choice of either saving for their own retirement or consuming all of their income before they retire and receiving the means tested benefit. The potential means tested benefit acts as a kind of tax on their saving, reducing the incremental retirement consumption that saving would produce. A rational individual would decide whether to act as if he or she is myopic by comparing the lifetime utilities with optimal positive saving and with no saving. Those with relatively high incomes would not be tempted by the means tested benefit. But others with lower incomes would have higher lifetime utility by increasing their consumption during working years even if the means tested benefits would only provide lower consumption during retirement than optimal saving would allow. Although they would achieve higher lifetime utility through their action, their benefits would be financed by tax-financed transfers that would make others worse off.

There is no way for the government to distinguish between the genuinely myopic and those who are rational utility maximizers gaming the system. The government could in principle set the means tested benefit so low that very few rational individuals would be tempted. My judgement is AER.Jan3 
that our relatively affluent society would not accept that policy. The means tested benefits would be set at a higher level that would tempt many rational individuals to save nothing.

A policy of forcing everyone to save for his or her own retirement would eliminate the problem of those who game the system. The only adverse effect of such a policy is that some individuals might be required to shift more of their lifetime consumption to their retirement years than they would prefer. For them, part of the mandatory saving would be a tax to the extent that they valued the saving less than current consumption.

The choice between such a mandatory saving plan - essentially a kind of investment-based social security pension - and a means tested benefit should depend on numbers. How many people would receive means tested benefits? How much deadweight loss would be involved in financing those benefits? How many people in a mandatory saving plan would have to provide more for their retirement than they want?

In the absence of such a mandatory investment-based option, the policy choice is between a means tested program and a universal pay-as-you-go retirement benefit. Such a pay-as-you-go plan forces all individuals (after the initial generation) to receive a lower rate of return than they could obtain on private saving. As such, it also imposes a tax on labor income since each extra dollar of earnings would induce an additional pay-as-you-go tax liability. And the reduction in saving that is induced by the pay-as-you-go system also causes a fall in capital income and therefore in corporate and personal tax revenue that requires higher marginal tax rates to recover the lost revenue.

Both of these examples of asymmetric information show that a social insurance program may be an appropriate response to a market failure but that it need not be. Even when there is a market failure, it may be better to do nothing or to have a means tested welfare program. The choice AER.Jan3 
depends in part on the relative costs of the different options and those in turn depend on the design of the potential social insurance program. Whether such a program is investment-based or purely tax financed on a pay-as-you-go basis is an important feature of that cost.

Economists can help to evaluate these choices by estimating the relevant costs and benefits of the different options. My own conclusion is that investment-based social insurance programs for retirement, unemployment, and health care of the retired population are more appropriate than either pay-as-you-go programs, means-tested programs, or a policy of doing nothing.

There is an important political economy reason for economists to work on improving the design of social insurance programs rather than advocating means tested programs for unemployment and old age. Elected governments will inevitably seek to create universal benefits to capture political support from the largest possible majority of voters. Bismark introduced social insurance in Prussia in 1881 in an attempt to win support for his conservative government and to fend off the appeal of the nascent social democrats. Even if it were economically desirable to do so, economists could not prevent the spread of social insurance by arguing that means tested programs would be more efficient. If economists don't analyze the effects of social insurance programs and recommend rules that reflect good economics, the political process will inevitably produce inferior programs.

\section{Principles of Social Insurance}

Accepting that there is a reason for mandatory social insurance programs does not imply the appropriateness of the programs that we have inherited from the past. Today's Social Security and unemployment insurance were enacted nearly 70 years ago. Economic conditions, administrative technologies, and assumptions about economic behavior have all changed dramatically since then.

AER.Jan3 
And yet during these past 70 years, the key social insurance programs have expanded without fundamental change.

Before I consider some of the specific ways in which our basic social insurance programs can be reformed and strengthened, I want to discuss broader principles that can help us to think about each of the specific programs. I'll begin with three fundamental political principles and then turn to four economic principles.

\section{A. Three Political Principles}

Political principles involve value judgements to a greater extent than the economic principles to which I will turn later. I can explain the political principles that shape my view about appropriate reforms but I cannot prove that they should determine policy. You may or may not agree with them. Of course, you might agree with me about specific reforms even if you reject some or all of these principles.

\section{1. $\quad$ Permitting individual choice}

Individuals differ in their preferences. We do not all have the same risk aversion, the same time preference, the same relative taste for goods and leisure. Letting individuals choose among options in a way that reflects their individual preferences should be an important aspect of social insurance design. For Milton Friedman, such freedom to choose is paramount. For me it is important but not decisive. In cases where asymmetric information creates serious efficiency problems, Imight restrict that choice. But I prefer to allow as much choice as possible. I think that allowing individuals to make their own choices is morally correct and generally improves individual and therefore social well-being. AER.Jan3

But allowing choice means that programs should be designed so that choice enhances 
economic efficiency rather than creating deadweight losses. A good example of such a program redesign was the Social Security reform that introduced the actuarial adjustment for early and delayed retirement in a way that, in principle, will allow individuals to decide when they will start collecting benefits without changing the actuarial present value of their benefits ${ }^{5}$.

\section{2. $\quad$ Creating Program Transparency}

Social insurance programs involve complex rules about the benefits to be received, the taxes to be paid, and the link if any between them. Who among you is confident about even the most basic Social Security rules that determine benefits at retirement? If you are a man, what benefit would your wife receive if she collects on her own rather than as your spouse? How would that change if she earned more or worked another year? If she retires at age 62 rather than 65? I'm told that there are more than 2500 separate rules in the Social Security handbook.

The complexity of the rules weakens the perceived link between the payroll taxes paid and subsequent benefits. Many employees may simply regard their Social Security payroll tax as similar to the income tax, thereby increasing the perceived marginal tax rate and raising the deadweight loss of the tax.

Lack of transparency also permits programs to have effects that might not be politically acceptable if they were more explicit. For example, some defenders of the current Social Security system believe it permits a substantial amount of redistribution that Congress would not be willing to build into an investment-based system of individual accounts. Although the Social Security rules do not actually achieve that redistribution, the important political principle is that it is inappropriate in a democracy to use a deliberately opaque system to achieve a redistribution of income that would be rejected if proposed in a more transparent way. AER.Jan3 
The Social Security program lacks transparency because it is a defined benefit system rather than a defined contribution plan of the sort that now characterizes most private pensions. Converting Social Security to a defined contribution plan - even an unfunded "notional" system such as Sweden and Italy now have - would allow individuals to see the link between their taxes and the resulting benefits. An explicit decision by the Congress to supplement the contributions of low income earners in such a defined contribution plan would achieve income redistribution without a loss of transparency.

\section{Recognizing Political Dynamics}

When we economists talk about policy design, we generally think about enacting permanent reforms. But experience shows that legislated rules do change and that the initial conditions influence the path of that change. When designing a particular program or advocating a particular design, economists should recognize that some designs are more stable than others and should anticipate how a program might evolve.

The Medicare drug legislation enacted in 2003 is a good example. Medicare beneficiaries will pay the first $\$ 250$ a year in drug expenses, followed by a 25 percent coinsurance rate to a maximum benefit limit. Patients must then pay 100 percent of the drug cost up to $\$ 3600$ in out-of-pocket payments (in 2006). Above that, Medicare will pay 95 percent of any additional drug costs.

This rather strange design was accepted to limit the total cost of the plan while delivering benefits to a very large number of senior citizen voters. An economically more rational plan with the same budget cost would have insured at least part of the range that is currently uninsured and kept total costs down by a larger deductible. But that would have had the political disadvantage of giving 
benefits to fewer individuals. It seems likely that future legislation will address the residual insurance gap in a way that will raise the total cost of the program.

There is another and potentially more significant aspect of the future evolution of this Medicare drug program. If all of the drugs consumed by seniors come to be covered by government insurance, there will be strong pressure to regulate the price of those drugs. Such price regulation is in turn likely to discourage the development of drugs for those diseases that particularly affect the elderly. It would be sadly ironic if an insurance plan initiated to improve drug access for seniors led ultimately to a reduced availability of new drugs for this group.

\section{B. Four Economic Principles}

Let me turn now from these three political principles - permitting individual choice, creating program transparency, and recognizing political dynamics - to four economic principles.

\section{Recognizing the economic effects of social insurance programs and their taxes}

Noneconomists who write about social insurance programs often implicitly assume that social insurance programs do not affect the behavior of beneficiaries or the overall performance of the economy. Evidence shows that the opposite is true. Social insurance programs have important and sometimes harmful effects on the economy that are not fully recognized by the public, the Congress, or the politically responsible officials.

A substantial volume of work during the past quarter century has shown the various ways in which social insurance programs do affect individual behavior and the overall economy. These effects include reducing national saving, inducing early retirement, raising the unemployment rate, pushing up the cost of health care, and crowding out private health insurance. Any serious

AER.Jan3 
evaluation of social insurance programs and any attempt to improve their design should take these effects into account.

There is, of course, controversy about the magnitude of these effects, just as there is about most other economic parameters. Decisions about program design have to use the evidence that is available, even if parameter estimates come with substantial uncertainty. But there is clearly room for economists to use new data, new statistical methods, and new natural policy experiments to improve our knowledge and therefore to improve policy design.

Adverse effects result from specific program designs and are not inherent in the goals of the programs. For example, John Gruber and David Wise (1999) showed that the rules governing retirement benefits induce early retirement in several European countries but that different rules at different times and in other countries did not induce early retirement. The U.S. benefit rules that now specify an almost actuarially fair relation between benefits and retirement age reduces substantially the perceived bias in favor of early retirement.

More generally, social insurance programs not only distorts economic behavior directly, thereby creating deadweight losses, but also creates further deadweight losses because of the taxes that are levied to finance those programs. I believe that the deadweight losses of those taxes are much larger than is generally recognized.

I will illustrate this with the effect of the 50 percent increase in the payroll tax rate that could occur if there is no change in benefit rules. Deadweight losses depend on marginal tax rates. Consider an individual who now faces a combined federal and state marginal rate of income tax of 30 percent without social insurance. The current 15.3 percent employer-employee payroll tax rate ${ }^{6}$, when adjusted for the interaction with the income $\operatorname{tax}^{7}$ and for the present actuarial value of the AER.Jan3 
additional retiree and survivor benefits that result from increased taxable earnings, now increases the overall marginal tax rate from 30 percent to about 37.7 percent. $^{8}$ A 50 percent rise in the 15.3 percent marginal tax rate, adjusted for the income tax interaction, would increase this effective marginal tax rate from 37.7 percent to 44.2 percent. $^{9}$

The increase in the deadweight loss that would result from this tax increase reflects both the reduction in labor supply - broadly defined to include not just working hours but also the accumulation of human capital, the choice of occupation, effort, etc. and the change in the form of compensation - away from taxable cash and to less valuable fringe benefits. Although neither behavioral change can be measured explicitly, the resulting deadweight loss can be calculated empirically by estimating the extent to which the higher payroll tax would reduce taxable labor income. It is appropriate to focus on the decline in taxable labor income without evaluating the two separate effects because the relative price of the two components - the marginal rate of tax on the reward for increased labor supply and the marginal tax rate that determines the net cost to the taxpayer of fringe benefits - remains the same when the tax rate changes. Taxable labor income is therefore a Hicksian composite good that can be used to assess the deadweight loss (Feldstein, 1999a). ${ }^{10}$

The elasticity of taxable labor income with respect to the net-of-tax share, i.e., to one minus the marginal tax rate on labor income, is much greater than the traditional elasticity of labor supply as measured by labor force participation and average hours worked. Estimating this elasticity is now a subject of very active research among public finance economists. Although a wide range of estimates has been produced, some studies are more reliable than others. I believe that a AER.Jan3 
conservative estimate is that the compensated elasticity of taxable income with respect to the net of tax rate is one-half.

Using this elasticity and the 2004 size of the taxable payroll implies that a rise in the effective marginal tax rate from 37.7 percent to 44.2 percent increases the annual deadweight loss by $\$ 96$ billion or nearly one percent of GDP. ${ }^{11}$ Since the 6.5 percent increase in the marginal tax rate applies only to taxable labor income (about 40 percent of GDP), the deadweight loss is equal to about onethird of the incremental tax revenue. Even this understates the relative size of the deadweight loss because it ignores the reduction in the tax base and therefore in the tax revenue that results from the higher marginal tax . When that reduction in taxable income is taken into account, the incremental deadweight loss is nearly 50 percent of the incremental revenue. ${ }^{12}$ The true cost per additional dollar of payroll tax revenue is there $\$ 1.50$.

Note that this is just the deadweight loss or excess burden - i.e. the pure waste - associated with the incremental tax. It does not include the deadweight loss of the existing tax or the direct burden of the taxes themselves. And it does not include the deadweight loss caused by the program distortions.

Although scaling back the rise in future benefits would reduce the increase in the deadweight loss, it would also reduce the protection that Social Security provides to future retirees. An alternative approach is therefore to redesign the program so that the increased financing required for the aging population has less of the character of a tax.

One way to do that is to strengthen the taxpayers perception of the link between taxes paid and future benefits. That is one of the advantages of shifting from the existing complicated defined benefit rules to a defined contribution system, even to a notional defined contribution system. AER.Jan3 
Although a notional defined contribution plan would remain a pay-as-you-go system, it would clearly link each worker's social insurance tax payment to his or her resulting future benefits.

A defined contribution system would provide a tax-benefit link for those groups in the population that now receive no extra benefits at all in exchange for their additional taxes. For them the Social Security payroll tax is a pure tax just like the income tax. These include both young and older workers who are not in the top 35 wage-indexed earning years of their life, the basis on which Social Security benefits are calculated, as well as working women who will eventually claim benefits based on their husbands' earnings.

Although an unfunded notional defined contribution system would provide some remedy, the very low implicit rate of return in an unfunded system implies that the payroll tax would retain much of its distorting character. A pay-as-you-go plan that substitutes a two percent real return for private saving that would otherwise earn a five percent real return is equivalent over a lifetime of saving and dissaving to a tax rate of about 75 percent.$^{13}$

A much more substantial reduction in the effective tax rate would be achieved by financing the increased cost of Social Security and Medicare by a funded system that would permit future benefits to be financed without a large increase in the tax rate. Moreover, to the extent that the additional saving that individuals do earns a favorable rate of return, they might not consider it a tax at all. I will return to this issue later when I discuss Social Security reform more fully.

2. Designing programs by balancing protection and distortion while seeking reforms that improve the available tradeoff.

Social insurance programs generally involve a tradeoff of protection and distortion. Social insurance programs protect individuals against undesirably low levels of consumption during old age AER.Jan3 
or spells of unemployment or when hit by large medical bills. They also protect individuals from the need to work longer than health warrants, or to accept a job when further search would be adequately productive, or to forego appropriate medical care because of an inability to pay. But the same social insurance programs also distort incentives in ways that cause inefficient use of resources: early retirement, low saving, unproductively long job searches, and excessive consumption of medical care.

Social insurance program parameters should be chosen to balance protection and distortion. The level of Social Security benefits should reflect the fact that high benefits relative to previous income improve the protection against reduced consumption in old age but also depress saving and may induce early retirement. A high level of unemployment insurance benefits helps the unemployed to maintain consumption but also encourages longer spells of unemployment and the choice of jobs that have a greater likelihood of leading to a layoff. Low copayments in health insurance reduce the risk of forgoing needed care or suffering a major drop in other consumption but they also lead to an increased demand for care that is worth less than its cost of production. More complete protection in each program also raises the program cost and therefore creates greater distortions through the tax system.

As protection becomes more complete, the marginal value of protection declines and the incremental distortion rises. The primary goal of social insurance should therefore generally be to prevent catastrophic losses: poverty in old age, long-term loss of income when unemployed, very expensive out-of-pocket medical costs, and the consequences of permanent disability. More generally, at the optimum, the marginal value of additional protection should just equal the marginal cost of the distortion. Economists can help the policy process by evaluating the protection and distortion created by different changes in program design.

AER.Jan3 
Useful economic analysis can go beyond selecting an optimal point on a protection-distortion frontier. It is important to seek ways to shift the frontier, permitting less distortion at each level of protection. Reforms based on individual accounts that I describe later in the paper would achieve that improvement.

\section{3. $\quad$ Redesigning Programs to Keep Pace with Changing Conditions}

Three important changes that should influence the design of our social insurance programs have occurred since those programs began: a changed economy, new technology, and a different understanding of the effect of government programs on individual behavior.

The Social Security and unemployment insurance programs were created during the depression of the 1930s when individual savings had been destroyed by widespread bank failures and when many individuals had been unemployed for a year or more because of a lack of aggregate demand. Keynesian economists in the 1940s like Harvard's Seymour Harris praised the unfunded character of the new Social Security program for its ability to depress national saving and stimulate aggregate demand. (Harris, 1941). In contrast to those depression years, conditions in the past half century have been very different, with relatively low unemployment rates and a system of government deposit insurance that protects individual savings. The unemployment insurance and Social Security that may have been appropriate in the $1930 \mathrm{~s}$ is no longer appropriate for the economy of the $21^{\text {st }}$ century.

A second relevant change has been in the technology of financial administration made possible by the introduction of computers. When Social Security was created, President Roosevelt wanted it to be a funded system rather than a pay-as-you-go system ${ }^{14}$. There was of course no way to have individually controlled personal retirement accounts and the Republicans in Congress did not want AER.Jan3 
to trust the government to manage a large pool of funds. And since the Congressional Democrats were eager to start paying benefits, the result was a de facto shift to a pay-as-you-go structure. The creation of individual investment accounts for every adult would have been technically impossible in the 1930s is no longer even difficult. Today more than 90 million Americans own mutual funds, including IRAs and 401k plan accounts. In contrast to the formidable task in the 1930s of keeping track of everyone's Social Security account without the help of computers, the creation of a system of individual investment-based accounts would now be relatively easy.

The third important change has been in the economic profession's understanding of how fiscal incentives affect individual behavior. In the 1930s, economists assumed that individuals were so unresponsive to taxes and benefits that any behavioral response could simply be ignored. Most economists continued to ignore the adverse incentive effects even when the top marginal tax rate was over 90 percent, as it was from 1944 to 1963. The adverse effects of high unemployment insurance benefits on job search and on the choice of jobs were also ignored. Today economists recognize that high marginal rates of income tax and the marginal tax rates implicit in various benefit rules reduce taxable income and create substantial deadweight losses.

These three changes imply that if Social Security and unemployment insurance were being created now the programs would likely be significantly different from those in current law. Economists today would regard the adverse effect of Social Security on saving and capital accumulation as a deterrent to growth rather than as a favorable source of Keynesian demand. The widespread ownership of mutual funds, IRAs, and 401ks would be a natural starting point for any new social insurance program. And every aspect of behavior would be assumed to be more responsive to tax rates and program design.

AER.Jan3 
More generally, the reforms that will be enacted in the future will inevitably evolve as economists learn more and as the set of feasible options changes. An interesting example of this changing perception of what is feasible is the possible transition to personal retirement accounts in an investment-based Social Security program. About twenty years ago, when I served as chairman of the Council of Economic Advisers in the Reagan administration, the Social Security retirement program was on the verge of a crisis. The trust fund was about to reach zero and the projected taxes over the next few years were not large enough to pay the benefits specified in law. President Reagan appointed a bipartisan commission to find a solution. The resulting plan called for an acceleration of scheduled future tax increases, the taxation of Social Security benefits, and a variety of other smaller measures.

President Reagan was unhappy with these proposals and asked a small group of us in the administration whether there wasn't something better to be done, perhaps along the lines of the Chilean reform that used investment-based personal retirement accounts instead of a pay-as-you-go system. None of us could design a feasible transition to such a plan. It looked to me and to the others that accumulating funds to finance such personal retirement account annuities would involve a double burden on the transition generation that was both unfair and politically infeasible.

I now know that that was wrong. Research that Andrew Samwick and I have done in recent years (Feldstein and Samwick, 1998a,1998b,2002) shows that it would be possible to transition gradually to a completely investment-based plan without ever increasing the combination of pay-asyou-go taxes and personal retirement account (PRA) saving by more than 2 percent of payroll earnings or about 1 percent of GDP and without reducing the benefit that retirees receive from the combination of the traditional tax-financed program and the new investment-based annuities. ${ }^{15}$ The AER.Jan3 
key, we learned, is to have a transition in which the personal retirement account annuities gradually substitute for pay-as-you-go benefits, allowing the pay-as-you-go tax rate to decline and the PRA contribution rate to increase until the transition is complete

Of course, the demonstration that such a transition is feasible doesn't mean that it is desirable. A pure investment-based PRA plan would involve more risk than many individuals might want, a subject to which I will return later in this lecture. But a shift to a mixed system that avoids an increase in the payroll tax rate or in private saving might be an economic improvement. I'm sorry that I couldn't offer that solution when President Reagan asked for it.

My point in recalling this is that economic research has changed what we regard as feasible. Similarly, future research can and will develop new ways to provide social insurance protection with greater economic efficiency and more responsiveness to individual tastes. A basic principle of designing social insurance policies should be a willingness to accept such ideas when they become available.

\section{Separating Social Insurance from Income Redistribution}

As I indicated at the start of these remarks, social insurance programs are not means tested. Eligibility for benefits does not depend on the income or wealth of the recipient but on an event like reaching age 65 , beginning a spell of unemployment, or incurring a medical problem. Not surprisingly, the evidence that I cited makes it clear that today's social insurance programs do not redistribute income to the poor. Indeed, the positive correlation of income and longevity tilts the net benefit of Social Security and Medicare to households with higher lifetime incomes. The structure of unemployment insurance rules causes a similar shift in that program.

AER.Jan3 
There is of course a role for means tested programs that are more narrowly focused on individuals who demonstrate that they have low income or assets. Although I doubt the desirability of the myriad of existing in-kind programs like food stamps and housing subsidies (see Moffitt, 2003), I have no doubt about the appropriateness of transferring income to the very poor.

There is moreover a clear case for being more generous to some demographic groups than to others. The existing Supplemental Security Income program provides means tested benefits to those over age 65 whose Social Security benefits plus private resources do not together reach some minimal level. A more generous means tested program, targeted at individuals over age 75 , would not distort labor supply to the same extent that it would for younger ones. It is possible therefore to have more protection with less distortion in such a means tested program. It is a shameful feature of our Social Security system that, even with the Supplemental Security Income program, ten percent of those over age 65 are in poverty while Social Security provides nearly $\$ 500$ billion a year in benefits to individuals who are financially more comfortable.

To the extent that distributional concerns motivate the design of social insurance, the emphasis should be on eliminating poverty and not on the overall distribution of income or the general extent of inequality. Like most economists, I accept the Pareto principle that an economy is better off if someone gains and no one loses. This is true even if the gainer has above average income, causing a Gini coefficient measure of income distribution to shift to greater inequality. Although there may be spiteful egalitarians who reject this Pareto principle, I believe that most economists agree with me.

To see if you do, ask yourself whether you would think it would be a good thing if everyone at this lecture received $\$ 50$ by some magical process that did not decrease the income or wealth of AER.Jan3 
anyone not here today. Since we are an above income group, national inequality would rise. Nevertheless I think there are few here who would reject bestowing this extra wealth on us all.

This brings me to the end of my four economic principles of social insurance. I turn now to discuss how the three major forms of social insurance could be improved by shifting to a system that combines government insurance with individual investment-based accounts: Unemployment Insurance Savings Accounts backed up by a government line of credit, Personal Retirement Accounts that supplement ordinary pay-as-you-go Social Security benefits, and Personal Retirement Health Accounts that finance a range of Medicare choices.

\section{Unemployment Insurance}

Although unemployment insurance is a relatively small program with total federal and state outlays in 2003 of $\$ 39$ billion, it is particularly important because of its impact on macroeconomic performance. It is also significant as an illustration of how reforms have been able to reduce distortion while retaining protection for those who need it. Moreover, it is a form of social insurance where further reforms through investment-based accounts could achieve substantial economic gains.

The unemployment insurance program in the United States was created in 1935 in the depth of the depression. The program is administered by the individual states but under federal rules that substantially restrict the scope of state governments' actions. Benefits of a typical recipient are 50 percent of previous earnings and can be collected for up to six months. The European unemployment benefit programs are substantially more generous in both the relative level and the duration of benefits with clearly adverse effects on European unemployment rates.

Thirty years ago, when I began doing research on unemployment insurance (Feldstein, 1973a, 1973b), there was a general perception that unemployment benefits were relatively low and that they AER.Jan3 
had little or no effect on economic behavior. People were assumed to be unemployed solely because there was inadequate aggregate demand. Reformers focused on seeking increases in the level and duration of benefits to help those who were unemployed for what were assumed to be reasons beyond their own control.

We now know that perception was wrong. Unemployment insurance benefits raise the unemployment rate in a variety of ways that economists have now analyzed and measured. But back in the 1960s and 1970s, the higher unemployment rates that were actually induced by unemployment insurance were instead incorrectly perceived as due to inadequate demand. When the government tried to reduce this high structural unemployment with expansionary monetary and fiscal policies, the result was rising inflation. Fortunately, this is now better understood. Monetary policy no longer tries to reduce structural unemployment. But although unemployment insurance is therefore no longer a source of increased inflation, it continues to raise the rate of unemployment. This is a particularly serious problem in Europe where unemployment rates remain close to 10 percent.

The old notion that unemployment benefits were too low to affect the economy was the result of a misleading comparison of the average weekly unemployment benefit and the average weekly wage. Although the average benefit was only about 30 percent of the average wage of all workers, the unemployed had substantially lower pre-unemployment wages than the labor force as a whole. Unemployment insurance benefits actually averaged about 50 percent of the pre-unemployment income of those who received benefits, with even higher replacement rates in states that supplemented the basic benefit with payments for spouses and children. But even this substantially understated the relevant replacement rate because benefits were not subject to the income and payroll taxes that were levied on wages. Since the combined marginal rate of income and payroll tax for the spouse of a high AER.Jan3 
earning individual could then easily exceed 50 percent, the ratio of untaxed UI benefits to the individual's net-of- tax potential earnings could exceed 100 percent. For such a person, it was possible to have a higher net income by remaining unemployed than by returning to work.

Even significantly lower benefit replacement rates could have substantial adverse incentive effects, as a number of studies eventually showed. Although macroeconomists came to recognize that much unemployment was not of an involuntary Keynesian type but was productive search for good job matches, the accumulating evidence showed that UI benefits were inducing excessively long periods of search in which the gain from the marginal search was less than the value of the foregone output. For example, Larry Katz and Bruce Meyer (1990) showed that the probability that an unemployed person takes a job rises dramatically in the few weeks just before their benefits would expire. Jim Poterba and I (1984) found that the median value of the reported reservation wage of new UI recipients was actually higher than the wage on their previous job, that it was an increasing function of the UI replacement rate, and that it came down only very slowly during their spell of unemployment.

Longer durations of unemployment are not the only adverse effect of UI benefits. The practice of temporary layoffs in which unemployed individuals have a spell of unemployment but return to their original employer is substantially encouraged by high UI replacement rates (Feldstein, 1976, 1978a). High benefits also encourage individuals to accept work in firms with high seasonal or cyclical layoffs. That reduces the wage that such firms have to pay and thus subsidizes the expansion of those high unemployment industries.

As all of this became clear, the most obvious first reform was to include unemployment benefits in taxable income. Although there was initially strong opposition to this idea, it was hard AER.Jan3 
to argue with the position that cash income is cash income and should be taxed. The notion that taxing unemployment insurance would inappropriately burden the poor was clearly contrary to the fact that the income tax allows a substantial exclusion of income before any tax is levied. A poor UI recipient would pay no tax.

The initial legislative compromise was to include only half of UI benefits in taxable income and to do so only for relatively high income taxpayers. This provided a natural experiment that Gary Solon (1985) used to show that the relative duration of unemployment fell for those whose benefits were taxed. Later, in the Tax Reform Act of 1986, the UI benefits were fully subject to the income tax like all other forms of labor income.

Taxing UI benefits eliminated the possibility that an individual could have a higher net income from UI benefits than by working. It is hard to know what the aggregate effect on unemployment has been but my personal estimate is that the unemployment rate probably fell by about one-half percentage point after benefits were taxed, an effect equal to more than 500,000 jobs at any time.

The evidence that UI benefits cause substantial distortion led to analytic studies of the level of benefits that optimally balances distortion and protection. Martin Bailey (1978 ) presented an analytic model in which the optimal level of benefits depends on the individual's coefficient of relative risk aversion and on the elasticity of the duration of unemployment with respect to the UI benefit replacement ratio. John Gruber (1997) used this framework to derive an explicit optimal UI benefit based on data on the effect of unemployment on household food consumption, concluding that the optimal replacement rate should be much less than the 50 percent in current law. More recently, however, Raj Chetty (2003) showed that the measure of risk aversion that is relevant to designing the optimal UI benefit may be substantially greater than the risk aversion that is relevant to financial AER.Jan3 
investments because many types of household spending cannot be adjusted in the short-run that is relevant to unemployment spells. Chetty's analysis points to optimal UI replacement rates that are close to the levels that we observe in the United States.

These calculations of optimal UI benefits assume that individuals have no financial assets. In contrast, if individuals save optimally, the optimal value of UI benefits - especially for short and moderate spells - would be very much less. Although there is evidence that individuals who face greater income uncertainty have somewhat higher saving rates, it would be wrong to assume that in the absence of unemployment insurance everyone would save enough to finance consumption optimally during spells of unemployment. Some individuals would be too short-sighted to save for potential unemployment.

What is the optimal response to this problem? One possibility would be to continue the current system of paying UI benefits but with the level and time path of benefits selected to balance the gain from protection and the loss from distortion. Another possibility would be to shift to a means tested program, although that would induce some individuals to game the system, saving nothing so that they could qualify for means tested benefits when they became unemployed. The same problem of asymmetric information would prevail as in the case of Social Security retirement benefits that I discussed before: the government could not distinguish individuals who were too shortsighted to save from those who were gaming the system. On efficiency grounds, the choice between the current system and government means-tested benefits would depend on the response of unemployment to the benefit level and on the relative number of those who would save optimally, those too shortsighted to save, and those who would choose not to save in order to qualify for the means tested benefits.

AER.Jan3 
A third possibility is to require everyone to have an Unemployment Insurance Saving Account earmarked to pay benefits if unemployment occurs. Dan Altman and I (Feldstein and Altman, 1998) explored a variety of such possible plans. In a typical plan, each individual would be required to accumulate funds in an Unemployment Insurance Saving Account until the balance was enough to pay benefits for two spells of six months at 50 percent of the individual's current wage. These funds would be invested and would earn a market rate of return. After a transition period to accumulate account balances, anyone who would be eligible for unemployment benefits under today's UI rules would instead be able to withdraw the same amount from his Unemployment Insurance Saving Account. If a balance remains in the account when the individual reaches retirement age, the funds would be available for the individual to take and spend. An individual who dies before retirement bequeaths the account balance. In short, individuals would regard the funds in the UISA as their own money. For someone who expects to have a positive balance in his account until retirement, the UISA plan would provide the same income protection as the current UI system but without any distortion.

What about individuals who experience so much unemployment that they use up the funds in their UISA? Such individuals would be able to borrow from a government UI fund to receive the same benefits that they would withdraw if they had a positive account balance. After they return to work, they would again save to repay the loan with interest and to rebuild their UISA balance. If they expect their account to accumulate a positive balance in the future, the dollars that they borrow would be a very real obligation and the incentives to return to work would not be distorted by the government loan. They would have full protection and no distortion while unemployed and would accumulate personal wealth after they returned to work.

\section{AER.Jan3}


It is only those who expect that they will have a negative balance in their account when they retire for whom this plan would represent no improvement over current law. For them the protection and distortion would be the same as it is with the current UI rules.

The extent of the gain from introducing Unemployment Insurance Saving Accounts therefore depends on the proportion of the unemployed who expect to retire with negative balances and on the sensitivity of unemployment to the change in incentives. Dan Altman and I did some preliminary empirical analysis of this approach using a sample of men in the National Longitudinal Survey. We found that, even with no favorable behavioral response of unemployment to the improved incentives, less than ten percent of benefits would be paid to those who eventually retire with negative balances (or who had negative balances when our data sample ended).

Our analysis thus implied that the UI program could be redesigned around individual Unemployment Insurance Saving Accounts in a way that substantially reduces the current distorting effect while not reducing either the availability of funds when unemployment occurs or the protection against relatively large cumulative amounts of lifetime unemployment. More research on this potential form of unemployment insurance would certainly be valuable.

\section{V. $\quad$ Social Security $^{16}$}

Social Security is the largest social insurance program in the United States with expenditures in 2003 of $\$ 470$ billion or 22 percent of total federal government spending. It includes not only annuities for retirees and survivors but also a separate program of disability insurance that accounts for some 15 percent of the total Social Security outlays. Since the disability insurance program involves a range of very different issues, I will not be considering it in these remarks.

\section{AER.Jan3}


Social Security is now a defined benefit, pay-as-you-go program in contrast to the defined contribution, investment-based structure of most private pensions. In a defined benefit program, an individual's benefit at retirement depends on his earnings during his working years and not on the performance of asset prices during that time. The program is a pay-as-you-go one because most of the payroll taxes collected in each year are used to pay concurrent benefits. There is not the kind of asset accumulation and financial investment that there would be in a private pension. The benefits are financed by a payroll tax on earnings currently up to about the $85^{\text {th }}$ percentile of the distribution of wages $(\$ 87,900$ in 2004$)$. The payroll tax rate devoted to the Social Security program other than disability is now 10.6 percent, divided equally between employers and employees.

Benefits take the form of an annuity that is indexed to the CPI to retain its real value during the individual's retirement years. The level of benefits at retirement depends on the average wageindexed earnings of the individual during his or her highest 35 earning years. The benefit formula provides higher annual benefits per dollar of previous earnings at lower earnings levels than at higher levels. Individuals who retire before their normal retirement age (now rising gradually from 65 to 67) receive an actuarially reduced benefit while those who retire after their normal retirement age receive an actuarially increased benefit.

Couples may collect benefits either on the basis of their separate earnings records or as 150 percent of the benefits of the individual with the higher benefit level. A surviving spouse can receive 100 percent of the benefit of the higher earning spouse. These rules for spouse benefits have the effect of causing many women who pay Social Security taxes to get little or nothing back for their taxes since their benefits are based on their husbands' incomes. This is true not only for married women

\section{AER.Jan3}


but also for younger women who expect to marry and for divorced women and widows who will also expect to claim benefits based on their former (or future) husbands' earnings.

I became interested in Social Security as a graduate student in the 1960s when I realized that the tests of consumption theory - Friedman's work on the permanent income hypothesis and Modigliani's work on life cycle saving - completely ignored the role of Social Security even though it had become the major source of retiree income. I realized also that the theory of Social Security's effect on saving was more complex than a simple displacement of financial wealth by Social Security. To the extent that Social Security induces earlier retirement, it raises the desired level of financial wealth. The net effect of Social Security on saving therefore depends on the balance between the positive induced retirement effect and the negative wealth displacement effect, an issue that could only be settled empirically.

My initial time series analysis (Feldstein, 1974) implied that Social Security "wealth", the present actuarial value of future Social Security benefits, significantly reduced personal saving. Reestimating this equation 22 years later with a corresponding amount of additional data produced reassuringly similar results (Feldstein,1996b) The conclusion that Social Security depresses private saving was also supported by household data and cross-country analysis. Other researchers who looked at this question generally supported the primary conclusion, although with estimates of varying magnitudes (Congressional Budget Office, 1998).

This adverse effect of Social Security on saving is relevant to understanding the significance of Paul Samuelson's very important 1958 overlapping generations paper (Samuelson, 1958). Samuelson showed that a pure pay-as-you-go Social Security system in an economy without capital and without technical progress would generate an implicit rate of return on each generation's taxes AER.Jan3 
equal to the rate of growth of the population. This occurs because the number of taxpayers is larger by the rate of growth of population than the number of retirees. If technical progress is added to this economy, the implicit return in a pure pay-as-you-go system is still the rate of growth of the tax base, now the sum of the growth rate of population and the growth rate of productivity.

Samuelson noted that this positive rate of return meant that an unfunded Social Security program could raise welfare in an economy that has no capital assets. But what happens when we recognize that all economies do have capital stocks and that Social Security transfers act as a substitute for real capital accumulation? With that more realistic description, the reduction in the rate of saving caused by the provision of pay-as-you-go annuities can cause a reduction in the present value of all current and future consumption.

To understand why, consider first an oversimplified textbook economy in which there are no capital income taxes. Each generation of workers receives an implicit pay-as-you-go return equal to the sum of population and productivity growth but foregoes the larger return equal to the marginal product of capital. For each such taxpayer generation, there is therefore a cost of having a pay-as-yougo Social Security program rather than providing for retirement consumption by saving and investing in real assets (or the financial assets that represent a claim on those real assets.) However, the initial generation of retirees had the good fortune to receive benefits without ever having paid taxes.

It can be shown that aggregating the consumption losses of all generations of taxpayers back to the initial date using a discount rate equal to the marginal product of capital produces a present value loss just equal to the windfall gain of the initial retirees. (Feldstein and Liebman, 2002a; Feldstein, 2005b) In short, with these simplified "textbook" assumptions, the introduction of a pay-as-you-go Social Security program does not reduce the present value of national consumption but only redistributes AER.Jan3 
it from later generations to the first one. More generally, whenever the program is expanded, those who are about to retire or who will soon retire receive a windfall gain at the expense of all future generations but with no change in the present value of consumption over all generations.

This neutrality result depends, however, on the implicit assumption that there are no distorting capital income taxes. ${ }^{17}$ With capital taxes, the appropriate intragenerational rate of discount of consumption is less than the marginal product of capital. Moreover, the appropriate rate for aggregating the consumption of different future generations may not be a market rate at all but a discount rate equal to the rate of decline in the marginal utility of consumption. With a realistic growth rate and any plausible value of the elasticity of marginal utility with respect to consumption, the appropriate rate of discount would be far less than the marginal product of capital. ${ }^{18}$ With that discount rate, the net present value of the loss of consumption due to introducing and then repeatedly expanding a pay-as-you-go Social Security would be very large. Similarly, shifting from a pure payas-you-go program to a mixed program with a substantial investment-based portion would cause a large rise in the present value of consumption.

The reduction in saving and in the present value of consumption is not the only adverse effect of a pay-as-you-go program. A second important effect is the distortion of labor supply and of the form in which compensation is paid because of the increase in the marginal tax rate. The relevant marginal tax rate is the statutory rate net of the anticipated increase in the actuarial value of benefits. The increase in benefits is zero for many married women. It is also zero for individuals who are not in one of their 35 highest earning years, typically when they are either young or old, so that the higher effective marginal tax rate comes when the individual's attachment to work is relatively weak. Many

\section{AER.Jan3}


individuals may also underestimate the effect of additional earnings on future benefits. In all of these cases, the payroll tax may create a substantial deadweight burden.

This incremental deadweight loss from distorting the labor supply would be essentially eliminated if individuals earned a market return on their Social Security savings, as they would in an investment-based system. That would make the actuarial present value of their benefits equal to the Social Security saving that they do. The only labor supply distortion would result if some individuals were forced to do more saving for retirement than they preferred or thought that the implicit actuarial terms of the annuity did not reflect their own mortality risk. A mixed system that combines pay-asyou-go and investment-based components would reduce but not eliminate the labor supply distortion.

A third distortion caused by a traditional pay-as-you-go system is the incentive to retire early when an implicit tax results from the loss of benefits caused by delayed retirement. Although the United States has now largely eliminated this by an appropriate actuarial adjustment, this distortion remains a major problem in Europe and elsewhere (Grubber and Wise, 1999). Early retirement increases the annual cost of the Social Security benefits and reduces the available labor income tax base. This leads to a higher marginal rate of Social Security tax, further increasing that source of deadweight loss. When combined with formal or informal restrictions that prevent reducing wages to offset the high payroll tax rates, these taxes contribute to the high unemployment rates that we see in Europe. The US experience shows that this problem can be eliminated within the pay-as-you-go system. It would of course also be eliminated in an investment-based system in which retirement income is withdrawn from personal accounts which can be bequeathed if the individual dies before exhausting the account or before annuitizing the accumulated balance.

\section{AER.Jan3}


The analysis of these three types of distortion should make it clear that the shift to a "notional" defined contribution system would only help a little to reduce the adverse effects of the current payas-you-go system. A notional defined contribution system is one in which each individual has an account that is credited with his tax payments and with a notional rate of return on his accumulated balance but in which there is no actual investment in financial assets. The notional rate of return that is feasible in the long-term is the modified Samuelson return, i.e., the rate of growth of the tax base. Since there is no real capital accumulation, the reduction in the present value of consumption is not changed. The distortion in labor supply and in the form of compensation is reduced (but not eliminated) because individuals can more clearly see the link between their taxes and their future benefits. A notional defined contribution system also reduces the distortion in retirement decisions because individuals reduce their future benefits if they retire early and increase them by delayed retirement. But even with this improved transparency, the low implicit pay-as-you-go rate of return leaves a substantial distortion in work and compensation incentives.

Although the scope for reducing the substantial deadweight losses of the pure pay-as-you-go system and for increasing the present value of all future consumption should provide a strong incentive for a change in policy, they are not the reason that has driven the political process in many countries to move from a pure pay-as-you-go to a mixed system or to consider such a change. The primary driving force is the recognition that the increasing age of the population will require a very large tax increase or benefit cut if nothing is done to change the existing system. This is not a temporary effect of the baby boom generation reaching retirement age but a permanent result of the trend to increased longevity. This demographic change is significant not only because it drives the political process but also because it increases the potential gain of making such a change.

\section{AER.Jan3}


The desirability of shifting to an investment-based or mixed system depends on four issues: (1) the transition process and its cost; (2) the ongoing administrative costs; (3) the riskiness of financial investments; and (4) the effect on the income distribution and especially on the poorest group. I have done work on these issues during the past decade, both alone and with colleagues Jeffrey Liebman, Elena Ranguelova and Andrew Samwick. I will now summarize what I have learned.

I commented earlier in this lecture on the transition problem when I discussed my experience with President Reagan. The common view that the transition from a pure pay-as-you-go system to a mixed system requires the transition generation to "pay double" - once to save for their own retirement and once to meet obligations to existing retirees - is wrong. As examples of what could be done, Andrew Samwick and I (1998a, 1998b, 2002) showed how the projected rise in the pay-asyou-go tax rate to more than 19 percent $^{19}$ could be avoided if individuals contribute just 1.5 percent of wages out-of-pocket to personal retirement accounts. The key to the transition is using personal retirement account annuities to supplement the pay-as-you-go benefits. The growth of the PRA annuities offsets the slowdown of the pay-as-go-benefits that results from not increasing the tax rate as the population ages.

There is no free lunch in this process. The key is that additional saving during the transition years can reduce long run costs. This extra saving could be voluntary, induced by a matching PRA contribution out of existing payroll tax receipts. ${ }^{20}$ Although the matching would reduce the "trust fund" balances, the transition need not involve borrowing by the Social Security system from general revenue (Feldstein and Samwick, 2002). ${ }^{21}$

\section{AER.Jan3}


Even a transition in which the initial personal retirement account deposits are financed wholly by government borrowing could eventually raise national saving and the present value of future consumption. Financing the initial deposit to personal retirement accounts by government borrowing would have no immediate direct effect on national saving because the increased budget deficit would be offset by the deposit of those funds into the personal retirement accounts. Over time, the availability of the PRA annuities could permit reducing the pay-as-you-go benefits (relative to those projected in current law) without lowering total retirement income. This reduction in the pay-as-yougo benefits would mean that the annual rise in the budget deficit would be less than the amount transferred to the PRA accounts. That difference would be an increase in national saving. ${ }^{22}$

I turn next to the issue of the administrative cost of PRAs. Some critics of PRAs argue that the administrative costs of a PRA program could offset all of their higher return relative to the pay-as-you-go system. Although there have been bad cost experiences in some countries, this certainly need not be so. Sweden's recent PRA program involves administrative costs equal to between 50 and 80 basis points of the assets, an amount that will come down further as the total assets grow since the administrative costs depend on the number of transactions and not on the value of the assets. TIAA-CREF operates an individual account system with a variable annuity for a charge of only 37 basis points. ${ }^{23}$

The issue of risk is an important consideration in both the pay-as-you-go and investment-based systems. Although pay-as-you-go programs do not have asset price risk, they have the political risk that future taxpayers may not be willing to raise taxes when demographic or economic changes would make it necessary to do so in order to finance promised benefits. The United States enacted benefit cuts in 1983 by increasing the age for full benefits. Many Latin American countries cut cash benefits AER.Jan3 
in the 1980s and 1990s. More recently Germany, Italy and Japan have announced or enacted reductions in state pension benefits. ${ }^{24}$ Perhaps the most reliable way to avoid future legislation that causes an unexpected reduction in retirement income is to develop a mixed system that does not require a future rise in the payroll tax rate.

The issue of asset price risk is more complex. On the basis of a substantial amount of research, I believe that a suitable mixed system that combines tax-financed pay-as-you-go benefits with investment-based PRA annuities can satisfy three conditions: a substantially lower long-term cost of financing retirement income than the tax projected for the pay-as-you-go system; a higher expected level of benefits from the combination of pay-as-you-go and the PRA annuities; and a very low probability that the actual level of combined benefits will be less than the pay-as-you-go benefits projected in current law. ${ }^{25}$ The low risk could be achieved by a combination of three things: the floor on retirement income provided by the pay-as-you-go benefits in the mixed system, restrictions on the investments that can be made in the PRAs, and explicit guarantees provided by either the government or the private market. Because individuals differ in their risk preferences, the solution that can best reflect those different preferences may be the availability of a variety of alternative guarantees from the private organizations that manage the PRAs and PRA annuities. (Feldstein, 2005a).

I turn finally to the issue of the distributional effect of the shift from our pay-as-you-go system to a mixed system. I have already discussed the evidence that the current Social Security system does very little redistribution and leaves some ten present of seniors with incomes below the poverty line. Women who were never married, widows, and particularly those who were widowed or divorced at a relatively early age generally have quite low benefits under current law and could do substantially

AER.Jan3 
better under a mixed system (Feldstein and Leibman, 2002b). Divorced women would benefit if the total of the husbands' and wives' PRA accounts are pooled and divided at the time of divorce.

While a PRA itself does not cause any income redistribution, the redistributive structure of the pay-as-you-go benefits could, in principal, be changed to make the combined benefit achieve any degree of redistribution.

In summary, it seems clear from the research that has been done that the current pay-as-you-go system could be gradually replaced with a mixed system that includes investment-based personal retirement accounts in a way that maintains or exceeds the benefits that are projected in current law while sharply reducing the long-run cost of achieving those benefits. This transition could be financed with relatively small additional PRA saving by individuals or by using existing payroll tax revenue. Even if the tax revenue is used, the initial fiscal deficit would not decrease national saving because of the concurrent increase in private saving. National saving would rise in the long run because the PRA savings would exceed the increased fiscal deficits.

A mixed system would eliminate the need for a future increase in the Social Security payroll tax and would therefore avoid the political risk that future taxpayers would be unwilling to raise taxes to finance promised benefits. It could be designed so that, despite the asset price uncertainty, there would be little risk that the combined benefits would be less than the currently projected pay-as-yougo benefits. The remaining asset-price risk could be substantially reduced by guarantees that could be produced by the private financial market.

\section{Medicare}

Medicare, the Federal health care program for those over age 65, is more difficult to reform than either unemployment insurance or Social Security. The program is more complex and the

\section{AER.Jan3}


reaction to proposed changes is often more emotional. And yet without reform Medicare costs will rise even more dramatically than the cost of Social Security retirement benefits, reflecting the increasing numbers of the very old (who consume relatively more medical care) and the changing medical technology that provides new opportunities to spend money to prolong life and to increase the quality of life.

Before looking at Medicare, it is useful to consider the basic theory of health insurance and the current way that the government provides a kind of quasi-social insurance for the population under age 65 by its favorable tax treatment of employer payments for health insurance. This is important in itself and suggests an approach that may be useful for reforming Medicare.

The basic theory of insurance implies that a risk averse individual will prefer an actuarially fair insurance policy to an uncertain and exogenous distribution of potential losses. But the distribution of potential health spending is not exogenous and the gain from risk reduction must be balanced against the distorting effect of insurance on the demand for care. As insurance becomes more complete, the marginal gain from additional risk reduction declines and the marginal deadweight loss from distorting the demand for health care rises. At the optimum level of health insurance (e.g., at the optimum coinsurance rate) there is a deadweight loss caused by the distortion in the demand for care because individuals, advised by their doctors, make decisions about diagnosis and treatment based on a net price of care that is very much less than the cost of producing that care. That level of insurance is however efficient because the deadweight loss from distorted demand is less than the gain from risk reduction.

In actual practice, the demand for health insurance is greatly increased by the tax treatment of excluding employer payments for health insurance from the taxable income of employees. AER.Jan3 
Allowing employees to buy health insurance with pretax dollars in this way changes the nature of health insurance. For someone with a marginal tax rate of 40 percent, the ability to buy health insurance at a cost of only 60 cents per dollar of premium substantially increases the demand for health insurance with low deductibles and low coinsurance rates. This increases the deadweight loss caused by the distortion in demand for care.

Direct attempts to eliminate or even reduce the tax subsidy or to constrain it by requiring minimum deductibles or coinsurance rates have not been politically successful. When the Reagan administration proposed to limit the employers' deduction for health insurance premiums it was unable to get any member of the President's own party to introduce the legislation in Congress.

Recently, however, Congress enacted legislation to shift the incentives away from excessive health insurance. The new Health Savings Account rules, enacted as part of the 2003 Medicare legislation, allows individuals or their employers to deposit up to $\$ 5000$ of pretax income into a Health Saving Account if they have a health insurance policy with an equally large deductible and with protection against catastrophic expenses. The individual foregoes the advantage of the tax-free income in the form of the employer paid premium but gets an even larger tax-free income in the form of the health saving account contribution. Assets in these IRA-like accounts earn tax-free investment income. Funds not spent in one year automatically carry forward to the future and can be used to finance any kind of health care without paying tax. Funds can also be withdrawn for any other kind of spending by paying tax at that time.

The Health Savings Accounts create a strong incentive to choose policies with high deductibles instead of the current comprehensive low-deductible and low coinsurance policies. This in turn should change the nature of the demand for care. Until the individual health spending reaches AER.Jan3 
the deductible limit, money spent on health care is the individual's own money and not that of an insurance company. Spending below the high deductible limit therefore would not have any of the distortion caused by current policies with low deductibles and low coinsurance rates. And the requirement that the policies provide protection for catastrophic levels of spending means that the most important form of protection is retained or increased at the same time that the distortions are reduced. ${ }^{26}$

Of course, anyone who spends several days in a hospital will exceed the deductible limit. At that point, the insurance company is paying for care as they would today and the patient and his doctor no longer have the incentive to be cost conscious. The favorable incentive effects of the HSA could be increased without reducing the individual's insurance protection by replacing the deductible with a 50 percent coinsurance rate on spending up to twice the level of the HSA saving deposit. For example, the limit associated with the $\$ 5000$ HSA deposit would shift from a $\$ 5000$ deductible to a 50 percent copayment on the first $\$ 10,000$ of care, causing significantly more individuals and health spending to be in the cost-conscious range.

The shift from the current tax-induced comprehensive insurance to large deductibles or coinsurance is not only a way to limit excessive health care spending, i.e, spending that individuals and their doctors recognize is less valuable to them than the cost of production. It is also a way of making health spending reflect each individual's preferences. While all of us want good health, the lifestyles choices that individuals make show that some of us value it more than others. Although we all understand the adverse health effects of obesity, smoking, and the lack of exercise, not everyone acts on this information. Many people knowingly make the tradeoff to enjoy more eating, to smoke, and to avoid the rigors of exercise. Just as people make different lifestyle choices, some are more AER.Jan3 
willing than others to sacrifice more of other consumption to increase spending on health care. The Health Saving Accounts will allow this expression of taste in health care spending instead of effectively inducing almost everyone to purchase high cost health care.

Health Saving Accounts may be a model for Medicare reform. If nothing is done, the cost of Medicare to the Federal government will rise from 2.4 percent of GDP now to about 6 percent by 2030 and 8 percent by 2050. The rising cost of Medicare is similar to but even more dramatic than the rising cost of Social Security retirement benefits. The remedy for this problem should have two components: changing the spending incentives to slow the growth of Medicare outlays, and using a mixed financing system to raise the needed funds without the sharp tax increase that would otherwise be needed (Feldstein and Samwick, 1997; Feldstein, 1999b).

If Health Saving Accounts are successful, the high deductibles and coinsurance that will evolve because of the Health Saving Accounts for those under age 65 may establish a precedent that will also affect future Medicare benefits and therefore the spending incentives of the Medicare population.

A mixed financing system for Medicare could combine a tax-financed Medicare annuity for retirees geared to the then-current cost of health care plus an opportunity for individuals during their working years to accumulate funds in Retirement Health Saving Accounts. These combined funds could be used at retirement to pay for the type of health plan that the retiree prefers: a comprehensive insurance plan of the type that Medicare now provides, or membership in a health maintenance organization that provides a managed care plan, or a lower cost plan with substantial deductibles and coinsurance. Alternatively, working age individuals could use the funds contributed annually to their Retirement Health Saving Account to purchase health insurance for their retirement years, thereby AER.Jan3 
minimizing the problem of asymmetric information in policy choice at retirement that would occur in buying insurance after retirement.

\section{Conclusion}

The reform of Social Insurance is clearly a work in progress in the United States and in other countries as well. Policy makers can do much to improve the major social insurance programs that protect the unemployed, the aged, and the ill. Economists can contribute to this process by improving our understanding of the effect of social insurance rules and by deriving new program designs. In these remarks I have emphasized the use of personal investment-based accounts created and regulated by the government and earmarked for unemployment benefits, for retirement income, and for health care during retirement. Such accounts have the potential to provide a better tradeoff of increased protection and reduced distortion. They also give individuals greater discretion in tailoring benefits to their own tastes.

I am an optimist about economic policy. I have spent this lecture talking about what is wrong with our current social insurance programs and what could be done to improve them in the future. I believe that the policy process does evolve and that economists have contributed to that evolution. We see that in the important reforms of the past two decades that I have described today. But there is still much for economists to do in designing better policies for the future and in educating the public and the political decision makers about the desirability of making such changes.

AER.Jan3 


\section{References}

Baily, Martin. “Some Aspects of Optimal Unemployment Insurance.” Journal of Public Economics, December 1978, Vol. X, Issue 3, pp. 379-402.

Chetty, Raj. “Optimal Unemployment Insurance When Income Effects are Large.” National Bureau of Economic Research (Cambridge, MA) Working Paper 10500, May 2004.

Congressional Budget Office, Social Security and Private Saving: A Review of the Empirical Evidence, Washington, DC: U.S. Government Printing Office, 1998.

Coronado, Julia Lynn, Don Fullerton and Thomas Glass. “The Progressivity of Social Security." National Bureau of Economic Research (Cambridge, MA) Working Paper 7520, February 2000. Feldstein, Martin. “A New Approach to National Health Insurance.” The Public Interest. 1971, No. 23. Lowering the Permanent Rate of Unemployment. Joint Economic Committee, U.S. Congress, 1973a.

. "Economics of the New Unemployment." Public Interest, Fall 1973b, No. 33, pp 4-42. . "Social Security, Induced Retirement and Aggregate Capital Accumulation."

Journal of Political Economy, September-October 1974, Vol. LXXXII, No. 5, pp. 905-926.

_ "Temporary Layoffs in the Theory of Unemployment. Journal of Political Economy, October 1976, Vol. LXXXIV, Issue 5, pp. 937-957.

_ . "The Effect of Unemployment Insurance on Temporary Layoff Unemployment." American Economic Review, December 1978a, Vol. LXVIII, Issue 5, pp. 834-846. . "The Welfare Cost of Capital Income Taxation," Journal of Political Economy, April 1978b Part 2, Vol. LXXXVI, No. 2, pp S29-51.

AER.Jan3 
_. "Should Social Security be Means Tested?" Journal of Political Economy,

June 1987b, Vol. XCV, No. 3, pp.468-484.

. "Lowering the Permanent Rate of Unemployment," Joint Economic Committee, U.S.

Congress, Washington, D.C., 1973.

. "The Missing Piece in Policy Analysis: Social Security Reform.” The Richard T. Ely Lecture.

American Economic Review, May 1996a, Vol. LXXXII, Issue 2, pp.1-14.

. "Social Security and Saving: New Time Series Evidence," National Tax Journal, 1996b, Vol.

XLIX, No. 2, pp. 151-164.

. Privatizing Social Security. Chicago: The University of Chicago Press, 1998.

_ _Transition to a Fully Funded Pension System: Five Economic Issues." in Horst Siebert, ed., Redesigning Social Security, Kiel, University of Kiel, pp,. 299-315, 1998b. ${ }^{215}$

_ . "Tax Avoidance and the Deadweight Loss of the Income Tax." Review of Economic and Statistics, November 1999, Volume LXXXI, No. 4, pp. 674-680.

_. "Prefunding Medicare.” American Economic Review, May 1999b, Vol. LXXXIX, Issue 2, pp. 222-27.

— "Comment on Peter Diamond, Administrative Costs and Equilibrium Charges with Individual Accounts.” John Shoven, ed., Administrative Aspects of Investment-Based Social Security Reform. Chicago: The University of Chicago Press, 2000, pp. 162-169.

_ "Reducing the Risk of Investment Based Social Security Reform." National Bureau of Economic Research (Cambridge, MA) Working Paper XXXXX, 2005a.

_ _ "Restructuring Social Security." National Bureau of Economic Research (Cambridge, MA) Working Paper XXXXX, 2005b.

AER.Jan3 
Feldstein, Martin and Altman, Dan. "Unemployment Insurance Savings Accounts." National Bureau of Economic Research (Cambridge, MA) Working Paper 6860, December 1998.

Feldstein, Martin and Gruber, Jon. “A Major Risk Approach to Health Insurance Reform.” James Poterba, (ed.), Tax Policy and the Economy, Chicago: University of Chicago Press, 1995, pp

Feldstein, Martin and Liebman, Jeffrey. "Social Security." in Alan Auerbach and Martin Feldstein, eds., The Handbook of Public Economics, Amsterdam: Elsevier Science, 2002a, pp. 2245 2324.

Feldstein, Martin and Liebman, Jeffrey. "The Distributional Effects of an Investment-Based Social Security System,” in M. Feldstein and J. Liebman, eds., Distributional Aspects of Social Security and Social Security Reform, Chicago: University of Chicago Press, 2002b, pp. 263-326.

Feldstein, Martin and Poterba, James. "Unemployment Insurance and Reservation Wages." Journal of Public Economics, Vol. XXIII, Issues 1\& 2, February-March 1984, pp 141-167.

Feldstein, Martin and Samwick, Andrew. "Social Security Rules and Marginal Tax Rates," National Tax Journal, March 1992, Vol. XLV, No. 1, pp. 1-22.

Feldstein, Martin and Samwick, Andrew. "The Economics of Prefunding Social Security and Medicare Benefits." Ben S. Bernanke and Julio J. Rotemberg, eds., NBER Macroeconomics Annual, Cambridge, MA: MIT Press, 1997, pp 115-147.

Feldstein, Martin and Samwick, Andrew. "The Transition Path in Privatizing Social Security." Martin Feldstein, ed., Privatizing Social Security. Chicago: Chicago University Press, 1998a, pp. 215260.

Feldstein, Martin and Samwick, Andrew. "Potential Effects of Two Percent Personal Retirement Accounts.” Tax Notes, May 4, 1998b, Vol. LXXIX, No. 5, pp. 615-620.

AER.Jan3 
Feldstein, Martin and Samwick, Andrew. "Potential Paths of Social Security Reform," in J. Poterba, ed., Tax Policy and Economy 2001, Volume 16, Cambridge, MA: MIT Press, 2002, pp 181224.

Feldstein, Martin and Siebert, Horst. Social Security Pension Reform in Europe. Chicago: The University of Chicago Press, 2002.

Friedman, Milton. Capitalism and Freedom. Chicago: The University of Chicago Press, 1962.

Goldberg, Fred and Graetz, Michael. "Reforming Social Security: A Practical and Workable System of Personal Retirement Accounts.” John Shoven, ed., Administrative Aspects of Investmentbased Social Security Reform, Chicago: The University of Chicago Press, 2000, pp. 9-37.

Gruber, Jonathan. “The Consumption Smoothing Benefits of Unemployment Insurance.” American Economic Review, March 1997, Vol. LXXXVIII, Issue 1, pp. 192-205.

Gruber, Jonathan and Wise, David. "Introduction and Summary." Jonathan Gruber and David Wise, eds., Social Security and Retirement Around the World, Chicago: The University of Chicago Press, 1999, pp. 1-35.

Harris, Seymour. Economics of Social Security. New York: McGraw Hill, 1941.

Katz, Lawrence and Meyer, Bruce. "The Impact of the Potential Duration of Unemployment Benefits on the Duration of Unemployment." Journal of Public Economics, February 1990, Vol. XLI, Issue 1, pp. 45-72.

Liebman, Jeffrey. "Redistribution in the Current U.S. Social Security System." Martin Feldstein and Jeffrey Liebman, eds., Distributional Aspects of Social Security and Social Security Reform, Chicago: University of Chicago Press, 2002, pp. 11-48.

AER.Jan3 
McClellan, Mark and Skinner, Jonathan. "The Incidence of Medicare." National Bureau of Economic Research (Cambridge, MA) Working Paper 6013, April 1997.

McHale, John. “The Risk of Social Security Benefit Rules Changes: Some International Evidence.” John Campbell and Martin Feldstein, eds., Risk Aspects of Investment based Social Security Reform, Chicago: The University of Chicago Press, 2001, pp. 247-282.

Moffitt, Robert. Means-Tested Transfer Programs in the United States. Chicago: The University of Chicago Press, 2003.

Samuelson, Paul. “An Exact Consumption Loan Model of Interest With or Without the Social Contrivance of Money, Journal of Political Economy, 1958, Vol. LXVI, pp. 467-482.

Schieber, Sylvester and Shoven, John. The Real Deal: The History and Future of Social Security. New Haven: Yale University Press, 1999.

Shoven, John. Administrative Aspects of Investment Based Social Security Reform, Chicago: The University of Chicago Press, 2000.

Skinner, Jonathan and Zhou, Weiping. "The Measurement and Evolution of Health Inequality: Evidence from the U.S. Medicare Population.” National Bureau of Economic Research (Cambridge, MA) Working Paper 10842, October 2004.

Solon, Gary. "Work Incentive Effects of Taxing Unemployment Benefits.” Econometrica, March 1985, Vol. LIII, Issue 2, pp 295-306.

AER.Jan3 
*. Professor of Economics, Harvard University, and President of the National Bureau of Economic Research. A shorter version of this paper was presented as the Presidential address of the American Economic Association. Although there are some references in this paper to my own work and to that of others, there is no attempt to survey the large literature on social insurance. I have posted a full list of my own papers on social insurance at www.nber.org/feldstein .

1.Many of the ideas presented here were developed in teaching my graduate public economics course at Harvard since 1969. I am grateful to the students in those classes for stimulating discussions and to Kathleen Feldstein, John Gruber, Caroline Hoxby, Lawrence Kotlikoff, Jeffrey Liebman, James Poterba, Andrew Samwick, and Andrei Shleifer for comments on an earlier draft.

2.See Moffitt (2003) for detailed studies of a variety of welfare programs.

3.The unemployment tax is technically levied on the employer but the incidence is likely to be primarily on the employee.

4.Although Medicaid is a means tested program, more than half of its outlays are for nursing home care for the very aged rather than care for those with low lifetime incomes.

5.This adjustment will provide actuarially equivalent benefits with a 3 percent real rate of return. 6.The15.3 percent rate includes Medicare as well as the Social Security pension and disability taxes. Currently the pension and survivor insurance portion is 10.6 percent of taxable payroll. The disability tax is 1.8 percent and the Medicaid portion is 2.9 percent. The costs of these three components will rise at different speeds but the combined cost will eventually increase the required tax to 150 percent of the 15.3 percent rate.

7.Since the employer half of the 15.3 percent payroll tax is excluded from the personal income AER.Jan3 
tax base, the effective marginal rate of tax in this example is 30 percent plus the 7.65 percent paid by the employee plus 70 percent of the 7.65 percent payroll tax paid by the employer: $0.30+$ $0.0765+0.70(0.0765)=0.43$. The extent to which a labor supply response causes the tax to be shifted does not alter the appropriate calculation of the marginal tax rate.

8.Feldstein and Samwick (1992) show that the present actuarial value of the incremental benefits varies substantially among different age and demographic groups, from no value for young workers and some married women to more than a 100 percent offset of the incremental tax for older men with dependent wives. If this offset is approximated by 50 percent of the 10.6 percent of the old age and survivors portion of the tax, the 43 percent marginal tax rate calculated in footnote 8 is reduced to 37.7 percent.

9. The increase in the payroll tax rate is subject to the income tax offset (reducing the additional 7.65 percent to 6.5 percent). There is no incremental benefit associated with the higher tax rate. 10.The situation is more complex when we deal with taxes on capital income. These distort choices among financial instruments by both issuers and purchasers, choices about the form of business (corporate vs. noncorporate, domestic vs. foreign) and choices about saving vs. spending. The key elasticity that matters in the saving vs. spending distortion is not the elasticity of saving with respect to the net-of-tax return but the elasticity of future consumption with respect to that net of tax return; Feldstein (1978b). Saving is equivalent to expenditure on future consumption. The relevant elasticity is therefore much larger than the elasticity of saving. If saving does not respond to changes in the net interest rate, the relevant compensated elasticity is equal to one minus the marginal propensity to save.

11.The formula for the increase in the deadweight loss is $0.5 \mathrm{E}\left(\mathrm{t}_{2}{ }^{2}-\mathrm{t}_{1}{ }^{2}\right)$ TLI / $\left(1-\mathrm{t}_{1}\right)$ where TLI AER.Jan3 
is taxable labor income, $\mathrm{t}_{2}=0.442$ and $\mathrm{t}_{1}=0.377$. With TLI equal to 40 percent of GDP or $\$ 4.5$ trillion and $\mathrm{E}=0.5$, the implied increase in the deadweight loss is $\$ 96$ billion.

12.With a compensated elasticity of 0.5 and an income effect of 0.15 , raising the marginal tax rate from 37.7 percent to 44.2 percent on an initial tax base of $\$ 4.5$ trillion reduces taxable income by $\$ 199$ billion and therefore reduces tax revenue by $\$ 88$ billion. The net tax increase is thus reduced from $\$ 293$ billion to $\$ 205$ billion and the deadweight loss per dollar of incremental revenue increases to 46 percent. 13.An individual who can get a real net of tax rate of return of (say) 5 percent in an individual retirement account (IRA) or a 401k plan converts one dollar saved at age 45 (in the middle of his working life) to $\$ 4.32$ at age 75 (in the middle of his retirement). But if the implicit return on a pay-as-you-go Social Security tax is only 2 percent, the dollar paid into such a plan at age 45 only grows to $\$ 1.81$. The mandatory saving in the form of the low-return Social Security is therefore equivalent to a 75.6 percent tax (that reduces the gain of $\$ 3.32$ to $\$ 0.81$.)

14.See Scheiber and Shoven (1999) for a valuable discussion of the origins of the Social Security legislation.

15. Alternative plans could achieve the transition without any rise in taxes by allowing the Social Security Trust Fund to borrow for a temporary period.

16.Feldstein and Liebman (2002a) provides a survey for the Handbook of Public Economics of the large theoretical and empirical literature on Social Security. See also my Ely Lecture to the American Economic Association (Feldstein, 1996a) and a forthcoming article in the Journal of Economic Perspective (Feldstein, 2005b) that deals with the current reform debate in more detail. 17. For an explicit derivation of the neutrality result and an examination of the implication of capital income taxes and of other discount rates, see Feldstein and Liebman (2002a). AER.Jan3 
18. For example, with a per capita growth rate of two percent and an elasticity of the marginal utility function of two percent per year, the rate of decline of the marginal utility of consumption would be 4 percent.

19.The 19 percent is based on Social Security Administration's “intermediate" demographic and economic assumptions but ignores the effect of the higher tax rate of the size of the tax base for the payroll and personal income taxes.

20.The matching rate could be higher for low income individuals to assure very high levels of participation. In the extreme, the entire contribution for low income individuals could come from payroll tax revenue, requiring no contribution of their own. High income individuals would generally welcome a chance for more tax favored saving and could therefore be induced to participate with little or no matching.

21.Stated differently, the Social Security trust fund could remain positive and be rising at the end of the 75 year projection period, showing that the system has long-run stability.

22.Feldstein and Liebman (2002a, section 7.1.3) uses an overlapping generation model to show how such a debt financed transition could raise the present value of consumption. The rise in saving does not happen in the first period but begins after that. The debt service on the initial borrowing cannot be financed by additional borrowing alone; the growth of the debt must be less than the growth of the economy.

23.See Shoven (2000) for several discussions of administrative issues. The chapter by Goldberg and Graetz (2000) shows how administrative costs can be reduced while maintaining the individual account structure.

24.See McHale (2001) for more evidence on this point.

25.See Feldstein (2005a,2005b) for a more extensive discussion of the risk issue. AER.Jan3 
26.I discussed this type of health insurance reform in Feldstein (1971) and Feldstein and Gruber (1995).

AER.Jan3 